\title{
Two New Species of Alteromonas: Alteromonas espejiana and Alteromonas undina
}

\author{
K. Y. CHAN, $\dagger$ L. BAUMANN, M. M. GARZA, AND P. BAUMANN \\ Department of Bacteriology, University of California, Davis, California 95616
}

\begin{abstract}
A total of 32 amino-acid-requiring, gram-negative, polarly flagellated, marine, rod-shaped bacteria were submitted to an extensive phenotypic characterization. Numerical analysis of the data grouped the strains into three clusters, one of which was identified as Alteromonas haloplanktis. The strains in the remaining clusters had properties characteristic of the genus Alteromonas and were phenotypically distinct from each other as well as from the previously characterized species of this genus. One cluster was designated Alteromonas espejiana sp. nov. (type strain, 261 [= ATCC 29659]), and the other was designated Alteromonas undina sp. nov. (type strain, 272 [= ATCC 29660]).
\end{abstract}

The genus Alteromonas was initially proposed for species of gram-negative, polarly flagellated, rod-shaped, strict aerobes of marine origin which had guanine-plus-cytosine $(\mathrm{G}+\mathrm{C})$ contents in their deoxyribonucleic acids (DNA) of 40 to 50 mol\% (4). Organisms having these properties are common in the marine environment but appear to be rare or absent in terrestrial habitats. Originally the genus included four species: $A$. communis, A. vaga, A. macleodii, and A. haloplanktis $(4,15)$. All of these organisms utilize D-glucose and D-fructose by means of the EntnerDoudoroff pathway $(1,18)$. A. communis and $A$. vaga share a distinctive pattern of regulation of aspartokinase activity which differentiates them from marine species of Pseudomonas and $\mathrm{Al}$ caligenes (2). Recently, Gauthier characterized three additional species of Alteromonas-A. luteoviolaceus (9), A. rubra (10), and A. citrea (11) - which produce violacein, prodigiosin, and a noncarotenoid lemon-yellow pigment, respectively. A. rubra resembles the prodigiosin-producing, polarly flagellated, strictly aerobic marine isolates that have been studied by Lewis and Corpe (14). All three species are distinctive in that they produce a number of antibiotics $(8$, 11-13).

During a study of growth factor-requiring marine bacteria in our laboratory, it was found that a number of strains shared phenotypic properties that allowed their placement into three distinct groups in the genus Alteromonas. One of these groups was identical to the species $A$. haloplanktis, whereas the other two groups represented new species of Alteromonas, which are described in the present report.

$\dagger$ Present address: Dept. of Biology, University Science Centre, The Chinese University of Hong Kong, Shatin, N.T., Hong Kong.

\section{MATERIALS AND METHODS}

Bacterial strains. All of the isolates used in this study were obtained from seawater off the coast of Northern California by a direct isolation method previously described (4). Strain BAL-31 was a gift from R. M. Franklin.

Methods. The methods used for the phenotypic characterization of strains were previously described $(3,4)$. The sole modification consisted in the use of a basal medium containing (per liter) $1 \mathrm{mg}$ each of $\mathrm{L}$ alanine, L-arginine, L-asparagine, L-aspartate, L-cysteine, L-glutamate, L-glutamine, glycine, L-histidine, Lisoleucine, L-leucine, L-lysine, L-methionine, L-phenylalanine, L-proline, L-serine, L-threonine, L-tryptophan, and L-valine. The amino acids were filter sterilized and were added to the autoclaved medium, which had been cooled to $50^{\circ} \mathrm{C}$. Since the sodium ion requirement of each organism was tested in this medium, all of the amino acids used were potassium salts or hydrochlorides. The determination of the effect of $\mathrm{NaCl}$ on growth rate and yield was performed as previously described (17). The G+C contents of the DNAs of selected strains were determined by the thermal denaturation method (16).

Enzyme assays. Cells were grown on the basal medium of Baumann et al. (3) supplemented with $0.25 \%$ yeast extract (Difco), $0.25 \%$ tryptone (Difco), and $0.3 \% \mathrm{D}$-glucose, D-fructose, or L-alanine and harvested during the exponential phase of growth. The methods used for the preparation of cell extracts and for the assays of 6-phosphofructokinase (EC 2.7.1.11), 1-phosphofructokinase (EC 4.2.1.12), and 2-keto-3deoxv-6-phosphogluconate (KDPG) aldolase (EC 4.2.1.14) have been described by Sawyer et al. (18).

\section{RESULTS}

A total of 32 strains of gram-negative, rodshaped, strictly aerobic, marine bacteria were isolated which could grow in a medium containing $0.2 \%$ D-glucose, a mixture of amino acids, and an artificial seawater base. No growth occurred in media from which the amino acids 
were omitted or in which the $\mathrm{Na}^{+}$of the artificial seawater was replaced by equimolar amounts of $\mathrm{K}^{+}$. None of the strains denitrified, reduced $\mathrm{NO}_{3}{ }^{-}$to $\mathrm{NO}_{2}{ }^{-}$, or grew at $40^{\circ} \mathrm{C}$. A numerical analysis of the data grouped the strains, on the basis of their phenotypic similarities, into three clusters (Fig. 1). One cluster of six strains was phenotypically identical to previously characterized strains of $A$. haloplanktis $(4,15)$, and two strains of this cluster had $\mathrm{G}+\mathrm{C}$ contents of their DNAs of 43.1 and $43.9 \mathrm{~mol} \%$, values similar to those previously found for other strains of this species. The phenotypic properties of the remaining two groups (designated $\mathrm{J}$ and $\mathrm{K}$ ) are presented in Table 1. The G+C contents of the DNAs of strains 257 and 261 (group $J$ ) and 270 and 272 (group K) were 43.3, 43.1, 43.7, and 43.1 $\mathrm{mol} \%$, respectively. Both groups $\mathrm{J}$ and $\mathrm{K}$ were composed of strains that were motile by means of a single polar flagellum (Fig. 2 and 3). The cells from group $\mathrm{J}$ were straight rods (Fig. 4), whereas those from group $\mathrm{K}$ were curved (Fig. 5). The effects of $\mathrm{NaCl}$ concentration on the growth rate and cell yield of strains representative of groups $\mathrm{J}$ and $\mathrm{K}$, determined in the marine medium previously described (17) which contained $0.2 \%$ D-glucose and the amino acid mixture, are presented in Fig. 6. The optimal concentrations for strains 261 and 272 were about 125 and $150 \mathrm{mM}$, respectively. Some of the properties distinguishing groups $\mathrm{J}$ and $\mathrm{K}$ from the previously characterized species of Alteromonas are presented in Table 2 . Over 30 phenotypic traits distinguished groups $\mathrm{J}$ and $\mathrm{K}$ from $A$. communis and $A$. vaga, and between 4 and 15 traits distinguished these two groups from the remaining species of Alteromonas.

Cell extracts of strain 261 grown on D-glucose, D-fructose, or L-alanine, as well as extracts of strain 272 grown on D-glucose or L-alanine, lacked both 6-phosphofructokinase and 1-phosphofructokinase activities $(\leq 0.002 \mathrm{mmol}$ of substrate utilized per min per mg of protein). However, they did contain KDPG aldolase activity which, in L-alanine-grown cells, was 0.061 and 0.027 for strains 261 and 272 , respectively. In the case of the former strain, the activity increased about twofold in D-glucose (0.127)- or D-fructose (0.111)-grown cells; a similar increase occurred in D-glucose (0.62)-grown cells of strain 272 . These results suggest that, in these species, Dglucose and D-fructose are utilized via the Entner-Doudoroff pathway and not via the Embden-Meyerhoff pathway.

After the completion of the phenotypic characterization of groups $J$ and $K$, we became aware of the possible similarity of strain BAL-31 of Espejo and Canelo (5) to isolates of group J. This strain has been shown to have a G+C content of about $43 \mathrm{~mol} \%$ (7), a value similar to that of group J. A phenotypic characterization of BAL-31, restricted to the major diagnostic traits in Table 2, confirmed and extended the results of a previous characterization (5). Strain BAL-31 is an oxidase-positive, straight rod that is motile by means of a single polar flagellum, able to grow at 35 but not $40^{\circ} \mathrm{C}$, and produces an extracellular amylase, gelatinase, and lipase, but not an alginase or a chitinase. It is able to utilize D-galactose, sucrose, cellobiose, melibiose,

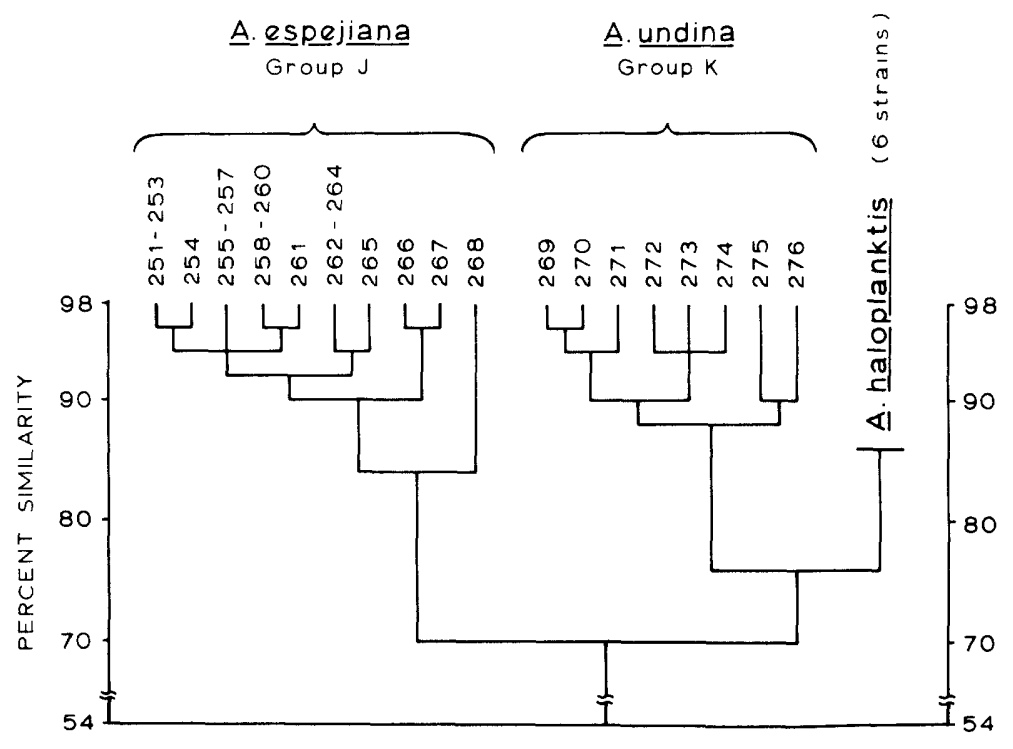

FIG. 1. Numerical analysis of strains of Alteromonas. 
TABLE 1. Phenotypic properties of A. espejiana and A. undina $a^{a}$

\begin{tabular}{|c|c|c|c|c|c|c|}
\hline \multirow[b]{2}{*}{ Trait } & \multicolumn{3}{|c|}{ A. espejiana (group J) } & \multicolumn{3}{|c|}{ A. undina (group $\mathrm{K}$ ) } \\
\hline & $\begin{array}{l}\text { Pheno- } \\
\text { type of } \\
\text { species } \\
{(18)^{b}}^{b}\end{array}$ & $\begin{array}{l}\text { Pheno- } \\
\text { type of } \\
\text { strain } \\
261\end{array}$ & Positive or negative strains & $\begin{array}{c}\text { Pheno- } \\
\text { type of } \\
\text { species } \\
(8)^{b}\end{array}$ & $\begin{array}{l}\text { Pheno- } \\
\text { type of } \\
\text { strain } \\
272\end{array}$ & $\begin{array}{l}\text { Positive or negative } \\
\text { strains }\end{array}$ \\
\hline \multicolumn{7}{|l|}{ Production of: } \\
\hline Amylase & + & + & $(+)$ : All strains & 5 & + & $(-): 273-275$ \\
\hline Gelatinase & + & + & $(+)$ : All strains & + & + & $(+)$ : All strains \\
\hline Lipase ... & + & + & $(+)$ : All strains & + & + & $(+)$ : All strains \\
\hline Alginase & + & + & $(+)$ : All strains & - & - & $(-)$ : All strains \\
\hline Chitinase & - & - & $(-)$ : All strains & + & + & $(+)$ : All strains \\
\hline \multicolumn{7}{|l|}{ Utilization of: } \\
\hline L-Arabinose & - & - & $(-)$ : All strains & 3 & + & $(+): 270-272$ \\
\hline D-Glucose & + & + & $(+)$ : All strains & + & + & $(+)$ : All strains \\
\hline D-Mannose $\ldots \ldots \ldots$ & 12 & - & $(-): 258-261,265,268$ & - & - & $(-)$ : All strains \\
\hline D-Galactose $\ldots \ldots \ldots$ & + & + & $(+)$ : All strains & - & - & $(-)$ : All strains \\
\hline D-Fructose $\ldots \ldots \ldots$ & 14 & + & $(-): 254,257,260,268$ & - & - & $(-)$ : All strains \\
\hline Sucrose $\ldots \ldots \ldots \ldots$ & + & + & $(+)$ : All strains & + & + & $(+)$ : All strains \\
\hline Trehalose $\ldots \ldots \ldots \ldots$ & + & + & $(+)$ : All strains & 7 & + & $(-): 276$ \\
\hline Maltose & + & + & $(+)$ : All strains & + & + & $(+)$ : All strains \\
\hline Cellobiose & 9 & + & $(+): 253,255-261,265$ & - & - & $(-)$ : All strains \\
\hline Melibiose & + & + & $(+)$ : All strains & - & - & $(-)$ : All strains \\
\hline Lactose & + & + & $(+)$ : All strains & - & - & $(-)$ : All strains \\
\hline$N$-Acetylglucosamine & - & - & $(-)$ : All strains & + & + & $(+)$ : All strains \\
\hline Acetate $\ldots \ldots \ldots$ & + & + & $(+)$ : All strains & + & + & $(+)$ : All strains \\
\hline Propionate & + & + & $(+)$ : All strains & + & + & $(+)$ : All strains \\
\hline Butyrate & 16 & + & $(-): 265,268$ & 6 & - & $(-): 272,273$ \\
\hline Isobutyrate $\ldots \ldots$ & 17 & + & $(-): 268$ & + & + & $(+)$ : All strains \\
\hline Valerate ............ & 13 & + & (-): $251,260,265,266,268$ & + & + & $(+)$ : All strains \\
\hline Isovalerate $\ldots \ldots \ldots \ldots$ & 16 & + & $(-): 265,268$ & - & - & $(-)$ : All strains \\
\hline Pelargonate $\ldots \ldots \ldots$ & + & + & $(+)$ : All strains & 7 & + & $(-): 276$ \\
\hline Caprate $\ldots \ldots \ldots \ldots$ & + & + & $(+)$ : All strains & + & + & $(+)$ : All strains \\
\hline Succinate .......... & - & - & $(-)$ : All strains & + & + & $(+)$ : All strains \\
\hline Fumarate $\ldots \ldots \ldots$ & - & - & (-): All strains & + & + & $(+)$ : All strains \\
\hline DL- $\beta$-Hydroxybutyrate . & 3 & - & $(+): 262-264$ & 7 & + & $(-): 273$ \\
\hline Citrate $\ldots \ldots \ldots \ldots$ & 17 & + & $(-): 268$ & - & - & $(-)$ : All strains \\
\hline Pyruvate $\ldots . . . \ldots \ldots$ & + & + & $(+)$ : All strains & + & + & $(+)$ : All strains \\
\hline Aconitate $\ldots \ldots \ldots$ & 17 & + & $(-): 268$ & - & - & $(-)$ : All strains \\
\hline Mannitol ............ & + & + & $(+)$ : All strains & - & - & $(-)$ : All strains \\
\hline Ethanol & - & - & (-): All strains & + & + & $(+)$ : All strains \\
\hline$n$-Propanol & - & - & $(-)$ : All strains & + & + & $(+)$ : All strains \\
\hline$n$-Butanol & 9 & + & $(+): 251-254,258-261,266$ & + & + & $(+)$ : All strains \\
\hline Glycine .. & 17 & + & $(-): 268$ & 7 & + & $(-): 269$ \\
\hline L- $\alpha$-Alanine & + & + & $(+)$ : All strains & + & + & $(+)$ : All strains \\
\hline L-Serine . . . . . . . & + & + & $(+)$ : All strains & + & + & $(+)$ : All strains \\
\hline L-Threonine & 17 & + & $(-): 268$ & 4 & + & $(+): 271,272,274,275$ \\
\hline L-Leucine & 15 & + & $(-): 262,264,268$ & + & + & $(+)$ : All strains \\
\hline L-Isoleucine & 9 & + & $(-): 255,257,260,262,264-268$ & 3 & - & $(+): 271,274,275$ \\
\hline L-Aspartate & 17 & + & $(-): 268$ & - & - & $(-)$ : All strains \\
\hline L-Arginine & 15 & + & $(-): 262,266,268$ & 2 & - & $(-): 271,273$ \\
\hline L-Citrulline & 16 & + & $(-): 258,259$ & 2 & - & $(+): 273,276$ \\
\hline L-Proline & 17 & + & $(-): 267$ & 6 & + & $(+): 269,270,272-275$ \\
\hline L-Tyrosine & + & + & $(+)$ : All strains & + & + & $(+)$ : All strains \\
\hline L-Phenylalanine & 14 & + & $(-): 253,257,260,268$ & 3 & - & $(+): 273-275$ \\
\hline Growth at $4^{\circ} \mathrm{C} \ldots$ & - & - & (-): All strains & 4 & - & $(+): 269-271,274$ \\
\hline Growth at $35^{\circ} \mathrm{C}$ & 8 & - & $(+): 252-254,256,262-264,267$ & - & - & $(-)$ : All strains \\
\hline
\end{tabular}

${ }^{a}$ Symbols: + , all strains positive; - , all strains negative; numbers indicate number of positive strains; numbers in italics indicate that the number represents $80 \%$ or more of the strains.

${ }^{b}$ Number of strains studied.

lactose, mannitol, and tyrosine but not D-mannose, salicin, D-gluconate, $N$-acetylglucosamine, succinate, fumarate, DL-glycerate, citrate, aconitate, erythritol, glycerol, or $\alpha$-ketoglutarate. With the exception of alginase, citrate, and aconitate, all the other traits of BAL-31 match those of group J. Therefore, we conclude that BAL-31 is a member of this group.

\section{DISCUSSION}

The strains of groups $\mathrm{J}$ and $\mathrm{K}$ are strictly aerobic, polarly flagellated, gram-negative rods that have $\mathrm{G}+\mathrm{C}$ contents of their DNAs of 43 to $44 \mathrm{~mol} \%$. All are of marine origin and require $\mathrm{Na}^{+}$for growth. These properties indicate their placement in the genus Alteromonas (4). Since 


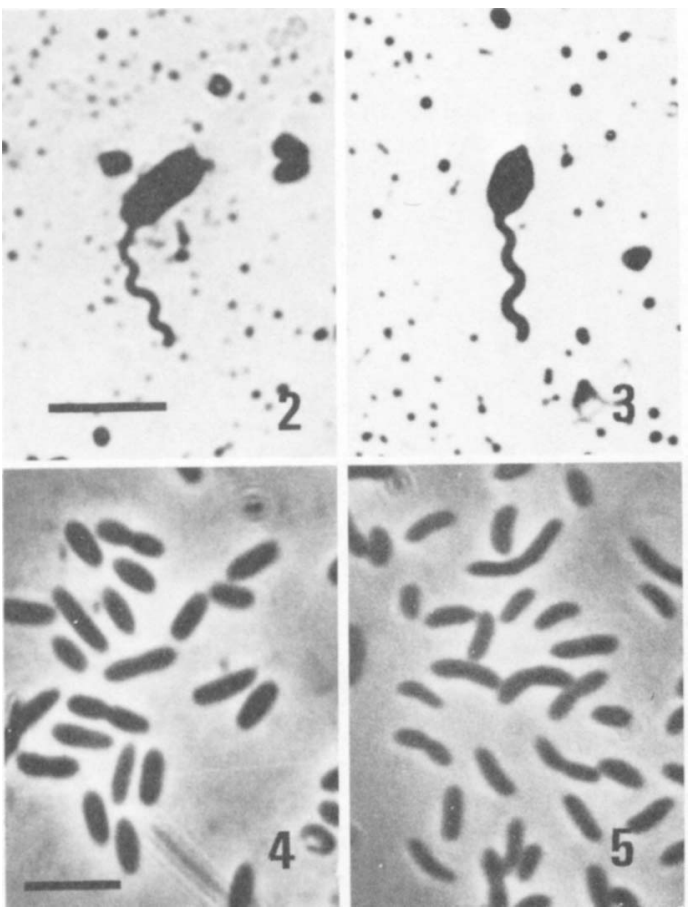

Fig. 2 and 3. Leifson flagella stains of A. espejiana 261 and A. undina 272, respectively. Magnification, $\times 2,500$. Marker represents $5 \mu \mathrm{m}$.

FIG. 4 and 5. Phase-contrast micrographs of $A$. espejiana 261 and $A$. undina 272, respectively. Magnification, $\times 2,000$. Marker represents $5 \mu \mathrm{m}$.

groups $\mathrm{J}$ and $\mathrm{K}$ are phenotypically distinct from each other as well as from the previously characterized species of this genus (Table 2), we propose that these two groups be given new species designations. Group $\mathrm{J}$ is named Alteromonas espejiana sp. nov. (es.pe.ji.a'na. M. L. adj. espejianus of Espejo; named for R. T. Espejo, a Chilean microbiologist), and group $\mathrm{K}$ is named Alteromonas undina sp. nov. (un'di.na. L. fem.n. undina undine, water nymph).

A. espejiana contains straight rods ( 0.2 to 1.0 $\mu \mathrm{m}$ in width and 2.0 to $3.5 \mu \mathrm{m}$ in length), each of which is motile by means of a single flagellum (Fig. 2 and 4). Its distinctive properties are the production of extracellular alginase, the ability to utilize D-galactose, sucrose, melibiose, lactose, citrate, aconitate, and mannitol, and its inability to utilize succinate, fumarate, or glycerol (Table 2). Strain 261 (= ATCC 29659) is the type strain of this species; its phenotypic properties, along with those of the species, are presented in Table 1. Strain BAL-31, which was characterized after the completion of this study, is a member of this species. This isolate is the host of a lipid-containing marine bacteriophage that has been the object of extensive investigation (6).

A. undina consists of curved rods ( 0.7 to 0.9 $\mu \mathrm{m}$ in width and 1.8 to $3.0 \mu \mathrm{m}$ in length), each of which is motile by means of a single flagellum (Fig. 3 and 5). Its distinctive properties are the production of an extracellular chitinase, the ability to utilize sucrose, $\mathrm{N}$-acetylglucosamine, succinate, and fumarate, and its inability to utilize D-galactose, melibiose, lactose, citrate, aconitate, mannitol, or glycerol (Table 2). Strain 272 (= ATCC 29660) is the type strain of this species; its phenotypic properties and those of the species are presented in Table 1.

The recent studies of Gauthier (9-11), as well as the present phenotypic characterization of two new species of Alteromonas, suggest that this genus be subdivided into two major groups, one consisting of the phenotypically similar species $A$. communis and $A$. vaga and the second consisting of $A$. macleodii, $A$. haloplanktis, $A$. luteoviolaceus, A. rubra, A. citrea, A. espejiana, and $A$. undina. The species in the latter group share a number of properties of which the most striking is the ability to make a number of extracellular hydrolases, an attribute that is generally absent in species of marine strains of Pseudomonas and of Alcaligenes (4).

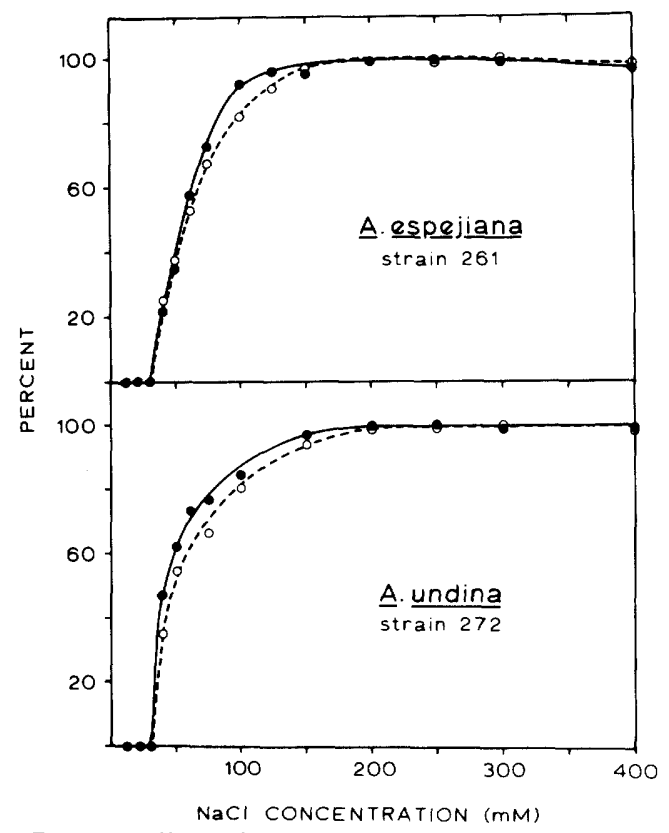

Fig. 6. Effect of $\mathrm{NaCl}$ on cell yield and growth rate of A. espejiana 261 and A. undina 272 tested in a marine medium (17). Symbols: $\bigcirc$, cell yield; $\bigcirc$, growth rate. All values have been normalized by making the maximal growth rate (doublings per hour during exponential growth rate) and yield equal to $100 \%$. 
TABLE 2. Some distinguishing properties of species of Alteromonas ${ }^{a}$

\begin{tabular}{|c|c|c|c|c|c|c|c|c|c|}
\hline Trait & $\begin{array}{l}\text { A. com- } \\
\text { munis }^{b} \\
(33)^{\mathrm{c}}\end{array}$ & $\begin{array}{c}A . \\
v a g a^{b} \\
(17)\end{array}$ & $\begin{array}{c}\text { A. ma- } \\
\text { cleodii }^{b} \\
\quad(21)\end{array}$ & $\begin{array}{l}\text { A. halo- } \\
\text { plank- } \\
\text { tis }^{d}(25)\end{array}$ & $\begin{array}{l}\text { A. espe- } \\
\text { jiana } \\
\text { (Group } \\
\text { J) (18) }\end{array}$ & $\begin{array}{l}\text { A. un- } \\
\text { dina } \\
\text { (Group } \\
\text { K) (8) }\end{array}$ & $\underset{\text { (3) }}{\text { Arubra }}$ & $\begin{array}{l}\text { A. luteo- } \\
\text { violaceus } \\
\quad(16)\end{array}$ & $\begin{array}{l}\text { A. citrea } \alpha^{\mu} \\
\text { (3) }\end{array}$ \\
\hline $\mathrm{Mol} \% \mathrm{G}+\mathrm{C}$ of DNA & 47 & 48 & 46 & 43 & 43 & 43 & 47 & 42 & 42 \\
\hline Straight rods ${ }^{h} \ldots \ldots \ldots \ldots$ & - & + & + & + & + & - & + & + & + \\
\hline Ring cleavage ${ }^{i}$ & $m$ & $m$ & - & - & - & - & - & $\mathrm{ND}^{\prime}$ & - \\
\hline Oxidase ..... & + & - & + & + & + & + & + & + & + \\
\hline Growth at $35^{\circ} \mathrm{C} \ldots \ldots \ldots$ & + & + & + & 21 & 8 & - & + & + & 1 \\
\hline Growth at $40^{\circ} \mathrm{C}$ & + & - & 15 & - & - & - & - & - & 1 \\
\hline Amino acid(s) required: . . . & - & - & - & 6 & + & + & + & ND & + \\
\hline \multicolumn{10}{|l|}{ Production of: } \\
\hline Amylase & - & - & 19 & 4 & + & 5 & + & 15 & + \\
\hline Gelatinase $\ldots \ldots \ldots \ldots$ & - & - & 20 & + & + & + & + & + & + \\
\hline Lipase $\ldots \ldots \ldots \ldots \ldots$ & - & - & + & + & + & + & + & + & + \\
\hline Alginase & - & - & 3 & - & + & - & ND & ND & ND \\
\hline$\ldots \ldots \ldots$ & - & - & - & 16 & - & + & - & - & 1 \\
\hline \multicolumn{10}{|l|}{ Utilization of: } \\
\hline D-Mannose & 29 & + & - & 21 & 12 & - & + & - & + \\
\hline D-Galactose $\ldots \ldots \ldots$ & 11 & 15 & + & 5 & + & - & - & ND & - \\
\hline Sucrose $\ldots \ldots \ldots \ldots$ & - & 1 & + & 23 & + & + & - & - & - \\
\hline Cellobiose $\ldots \ldots \ldots \ldots$ & - & 14 & + & - & 9 & - & - & - & - \\
\hline$\ldots \ldots \ldots \ldots$ & - & - & 20 & - & + & - & ND & ND & ND \\
\hline Lactose $\ldots \ldots \ldots \ldots \ldots$ & - & - & + & 1 & + & - & - & - & - \\
\hline Salicin $\ldots \ldots \ldots \ldots$ & - & - & + & - & - & - & - & ND & - \\
\hline D-Gluconate $\ldots \ldots \ldots$ & + & + & 18 & 1 & - & - & - & ND & - \\
\hline$N$-Acetylglucosamine & - & 15 & 7 & 23 & - & + & ND & ND & ND \\
\hline Succinate $\ldots \ldots \ldots \ldots$ & + & + & - & + & - & + & - & ND & - \\
\hline Fumarate $\ldots \ldots \ldots \ldots$ & + & + & - & + & - & + & - & ND & - \\
\hline DL-Glycerate . . . . . . . & 4 & - & + & - & - & - & ND & ND & ND \\
\hline Citrate $\ldots \ldots \ldots \ldots$ & + & + & - & 21 & 17 & - & - & ND & - \\
\hline Aconitate $\ldots \ldots \ldots$ & + & 16 & - & 21 & 17 & - & ND & ND & ND \\
\hline$\ldots \ldots \ldots$ & - & + & - & - & - & - & - & ND & - \\
\hline$\ldots \ldots \ldots$ & + & + & 9 & 11 & + & - & - & - & - \\
\hline$\ldots \ldots \ldots$ & + & + & + & - & - & - & - & - & - \\
\hline$\ldots \ldots \ldots \ldots$ & + & - & 17 & 20 & - & + & ND & ND & ND \\
\hline$\gamma$-Aminobutyrate $\ldots \ldots$ & + & 16 & - & - & - & - & ND & ND & ND \\
\hline L-Tyrosine $\ldots \ldots \ldots \ldots$ & - & - & 18 & 23 & + & + & ND & ND & ND \\
\hline $\begin{array}{l}\text { Sorbitol, DL-malate, } \alpha \text {-ke- } \\
\text { toglutarate, } m \text {-hydroxy- }\end{array}$ & & & & & & & & & \\
\hline benzoate $\ldots \ldots \ldots$ & + & + & - & - & - & - & - & ND & - \\
\hline Other traits $^{k} \ldots$ & + & + & - & - & - & - & ND & ND & ND \\
\hline Pigmentation & - & - & - & - & - & - & $+l$ & $14^{m}$ & $t^{n}$ \\
\hline
\end{tabular}

${ }^{a}$ Symbols: + , all strains positive; -, all strains negative; numbers indicate number of positive strains; numbers in italics indicate that the number represents $80 \%$ or more of the strains.

${ }^{b}$ Data from Baumann et al. (3).

${ }^{c}$ Number in parentheses indicates number of strains studied.

${ }^{d}$ Data from Baumann et al. (4), Reichelt and Baumann (15), and the present study.

' Data from Gauthier (10).

${ }^{\prime}$ Data from Gauthier $(9,10)$.

${ }^{g}$ Data from Gauthier (11).

${ }^{h}$ Symbols: +, straight rods; -, curved rods.

${ }^{i}$ Mechanism of aromatic ring cleavage by species capable of growth on aromatic compounds.

${ }^{j} \mathrm{ND}$, Not determined.

${ }^{k}$ Utilization of saccharate, meso-inositol, D-alanine, $p$-hydroxybenzoate, quinate, and sarcosine.

${ }^{l}$ Prodigiosin.

${ }^{m}$ Violacein.

${ }^{n}$ Lemon-yellow noncarotenoid pigment.

\section{ACKNOWLEDGMENTS}

We thank M. J. Gauthier for his interest and assistance. This investigation was supported by grant FD 000626 awarded by the Food and Drug Administration.

\section{REPRINT REQUESTS}

Address reprint requests to: Dr. Paul Baumann, Department of Bacteriology, University of California, Davis, CA 95616 . 


\section{LITERATURE CITED}

1. Baumann, L., and P. Baumann. 1973. Enzymes of glucose catabolism in cell-free extracts of non-fermentative marine eubacteria. Can. J. Microbiol. 19:302-304.

2. Baumann, L., and $P$. Baumann. 1974. Regulation of aspartokinase activity in non-fermentative, marine eubacteria. Arch. Microbiol. 95:1-18.

3. Baumann, P., L. Baumann, and M. Mandel. 1971. Taxonomy of marine bacteria: the genus Beneckea. J. Bacteriol. 107:268-294.

4. Baumann, L., P. Baumann, M. Mandel, and R. D. Allen. 1972. Taxonomy of marine eubacteria. J. Bacteriol. 110:402-429.

5. Espejo, R. T., and E. S. Canelo. 1968. Properties and characterization of the host bacterium of bacteriophage PM2. J. Bacteriol. 95:1887-1891.

6. Franklin, R. M. 1974. Structure and synthesis of bacteriophage PM2 with particular emphasis on the viral lipid bilayer. Curr. Top. Microbiol. Immunol. 68:107-159.

7. Franklin, R. M., M. Salditt, and J. A. Silbert. 1969. Structure and synthesis of a lipid-containing bacteriophage. I. Growth of bacteriophage PM2 and alterations in nucleic acid metabolism in the infected cell. Virology 38:627-640.

8. Gauthier, M. J. 1976. Modification of bacterial respiration by polyanionic antibiotic produced by a marine Alteromonas. Antimicrob. Agents Chemother. 9:361-366.

9. Gauthier, M. J. 1976. Morphological, physiological and biochemical characteristics of some violet pigmented bacteria isolated from seawater. Can. J. Microbiol. 22:138-149.

10. Gauthier, M. J. 1976. Alteromonas rubra sp. nov., a new marine antibiotic-producing bacterium. Int. J. Syst. Bacteriol. 26:459-466.

11. Gauthier, M. J. 1977. Alteromonas citrea, a new gramnegative yellow pigmented bacterium isolated from seawater. Int. J. Syst. Bacteriol. 27:349-354.

12. Gauthier, M. J., and G. N. Flatau. 1976. Antibacterial activity of marine violet-pigmented Alteromonas with special reference to the production of brominated compounds. Can. J. Microbiol. 22:1612-1619.

13. Gauthier, M. J., J. M. Shewan, D. M. Gibson, and J. V. Lee. 1975. Taxonomic position and seasonal variations in marine neritic environment of some gram-negative antibiotic-producing bacteria. J. Gen. Microbiol. 87:211-218.

14. Lewis, S. M., and W. A. Corpe. 1964. Prodigiosin-producing bacteria from marine sources. Appl. Microbiol. 12:13-17.

15. Reichelt, J. L., and P. Baumann. 1973. Change of the name Alteromonas marinopraesens (ZoBell and Upham) Baumann et al. to Alteromonas haloplanktis (ZoBell and Upham) comb. nov. and assignment of strain ATCC 23821 (Pseudomonas enalia) and strain c-Al of DeVoe and Oginsky to this species. Int. J. Syst. Bacteriol. 23:438-441.

16. Reichelt, J. L., and P. Baumann. 1973. Taxonomy of the marine, luminous bacteria. Arch. Mikrobiol. 94:283-330.

17. Reichelt, J. L., and P. Baumann. 1974. Effect of sodium chloride on growth of heterotrophic marine bacteria. Arch. Microbiol. 97:329-345.

18. Sawyer, M. H., P. Baumann, and L. Baumann. 1977. Pathways of D-fructose and D-glucose catabolism in marine species of Alcaligenes, Pseudomonas marina, and Alteromonas communis. Arch. Microbiol. 112:169-172. 